\title{
Two Restriction and Modification Systems in Staphylococcus aureus NCTC8325
}

\author{
By S. IORDANESCU AND MARIETTA SURDEANU \\ Institute Cantacuzino, Bucharest 35, Romania
}

(Received 19 January; revised Io April 1976)

\begin{abstract}
SUMMARY
The presence of two distinct host specificities in Staphylococcus aureus strain NCTC 8325 was revealed by the isolation of restriction- and modification-deficient mutants. The two host specificity systems, designated SI and S2, are both active on phage $80 \mu \alpha$ but are not additive in their restricting activity. Restriction-deficient, modification-proficient mutants were invariably affected in both restriction systems. The functional relationship between these two systems is discussed.
\end{abstract}

\section{INTRODUCTION}

Restriction and modification of DNA has been demonstrated in many bacterial species (Boyer, 1971), including Staphylococcus aureus (Rountree, 1956; Asheshov \& Jevons, 1963; Ralston \& Baer, 1964). However, most of our present knowledge about the genetics of host specificity comes from studies with enterobacteria. Recently, the isolation of restrictiondeficient mutants from several S. aureus strains was reported (Iordanescu, 1975; Stobberingh $\&$ Winkler, 1975). Of the 16 restriction-deficient mutants of $S$. aureus NCTC8325 that we had isolated previously, only one proved to be $\mathrm{r}^{-} \mathrm{m}^{-}$. In most previously studied hostspecificity systems about half of the isolated $\mathrm{r}^{-}$mutants are also modification deficient (Boyer, I97I); so we decided to isolate additional mutants of $S$. aureus NCTC8325 and examine their properties.

\section{METHODS}

Bacterial strains. Staphyloccocus aureus NCTC8325 and NCTC9789 (PS80) were obtained through the National Reference Centre for Staphylococcus lysotyping (Institute Cantacuzino, Bucharest). Two mutants of NCTC8325, SAI03 $\mathrm{r}^{-} \mathrm{m}^{-}$and SAII $3 \mathrm{r}^{-} \mathrm{m}^{+}$, isolated by Iordanescu (1975), were used. Strains RN450 (Novick, I967) and RN98I (Wyman, Goering \& Novick, 1974) were kindly supplied by Dr R. Novick.

Bacteriophages. Phage $80 \mu \alpha$, a derivative of phage 80 of the International Typing Set (Iordanescu, 1975), was used throughout. The notation of phage lysates and mutant phenotypes follows that of Arber \& Linn (1969).

Modification phenotype determination. A phage lysate obtained on each mutant isolated was tested for its efficiency of plating (e.o.p.) on NCTC8325 and the respective mutant.

Media. Nutrient broth contained ( $\left.\mathrm{g} \mathrm{1}^{-1}\right)$ : Difco Bacto peptone, 10; Difco Bacto beef extract, Io; $\mathrm{NaCl}, 5$. Phage agar was prepared from Difco Heart Infusion and contained $\mathrm{I} \cdot 5 \%$ (w/v) agar. Phage buffer was prepared according to Novick (1963).

Isolation of restriction-deficient mutants. The mutagenic treatment with $N$-methyl- $N^{\prime}-$ nitro- $N$-nitrosoguanidine (NTG) was by the method of Adelberg, Mandel \& Chen (1965). NTG was used at a concentration of $50 \mu \mathrm{g} \mathrm{ml}^{-1}$ at $37^{\circ} \mathrm{C}$ for $30 \mathrm{~min}$. 
Table I. Efficiency of plating of phage lysates obtained on $r^{-} m^{-}$mutants

\begin{tabular}{|c|c|c|c|c|c|c|}
\hline \multirow[b]{2}{*}{$\begin{array}{l}80 \mu \alpha \text { lysate } \\
\text { prepared on }\end{array}$} & \multicolumn{6}{|c|}{ Efficiency of plating* on strain: } \\
\hline & SAI I 3 & NCTC8325 & $\begin{array}{c}\mathrm{SA202} \\
\mathrm{SA203} \\
\text { and } \mathrm{SA282}\end{array}$ & SAIO3 & SA27I & $\mathrm{SA272}$ \\
\hline SAIO3 & $\mathbf{I} \cdot 0$ & $\mathrm{I} \cdot 0 \times 10^{-3}$ & $\mathbf{I} \cdot 0$ & $I \cdot O$ & $5^{\circ} 0 \times 10^{-3}$ & $4 \cdot 1 \times 10^{-4}$ \\
\hline SA2O2 & $\mathrm{I} \cdot \mathrm{O}$ & $2.5 \times 10^{-4}$ & $\mathrm{I} \cdot \mathrm{O}$ & $\mathrm{I} \cdot \mathrm{O}$ & $5.4 \times 10^{-3}$ & $6.3 \times 10^{-4}$ \\
\hline SA2O3 & $I \cdot O$ & $2 \cdot 2 \times 10^{-4}$ & $I \cdot O$ & $\mathrm{I} \cdot \mathrm{O} \times \mathrm{IO}^{-1}$ & $I \cdot 0$ & $1 \cdot 0$ \\
\hline SA27I & $I \cdot 0$ & $4.8 \times 10^{-4}$ & $1 \cdot 0$ & $1 \cdot 0 \times 10^{-1}$ & $I \cdot 0$ & $1 \cdot 0$ \\
\hline SA272 & $\mathrm{I} \cdot \mathrm{O}$ & $5.8 \times 10^{-4}$ & $1 \cdot 0$ & $7 \cdot 8 \times 10^{-2}$ & $I \cdot 0$ & $\mathrm{I} \cdot \mathrm{O}$ \\
\hline SA282 & $I \cdot 0$ & $8.6 \times 10^{-4}$ & $I \cdot 0$ & $\mathrm{I} \cdot \mathrm{O}$ & $6.2 \times 10^{-3}$ & $4.8 \times 10^{-4}$ \\
\hline
\end{tabular}

The screening procedure used has been described previously (Iordanescu, 1975) and involved replica plating on Heart-Infusion agar plates spread with unmodified phage stocks at a convenient concentration. As phage stock lacking NCTC8325-specific modification, we used phage $80 \mu \alpha . P S 80$ initially, and subsequently phage $80 \mu \alpha$ propagated on various modification-deficient mutants of NCTC8325.

Isolation of modification-deficient mutants. Colonies from a mutagenized culture grown on nutrient agar were inoculated to nutrient broth, incubated at $37^{\circ} \mathrm{C}$ for $3 \mathrm{~h}$ and then infected with phage $80 \mu \alpha$ at a multiplicity of about 2 . The resulting phage lysates were spotted on $\mathrm{r}^{-}$and $\mathrm{r}^{+}$strains to identify the modification-deficient clones.

In some experiments, the colonies were initially replicated on Heart-Infusion agar plates spread with an exponentially growing culture of either the non-lysogenic strain RN450 or one of its $\mathrm{r}^{-}$mutants, SA305. Colonies surrounded by a halo of lysis on SA305, but not on RN450, were tested as described above.

\section{RESULTS}

\section{Isolation of mutants}

Some 53 restriction-deficient mutants were isolated from a total of 4288 colonies tested by the replica-plating technique, and of these only two (SA27I and SA272) were deficient in the modification system.

Three modification-deficient mutants (SA202, SA203 and SA282) were isolated from 2220 colonies screened after NTG mutagenesis of one of the putative $r^{-} m^{+}$mutants (SAII3).

The difference between the incidence of restriction-deficient and modification-deficient mutants in NTG mutagenized cultures may be due to low efficiency of the method used to isolate modification-deficient mutants.

\section{Evidence for two restriction-modification systems in $\mathrm{NCTC} 8325$}

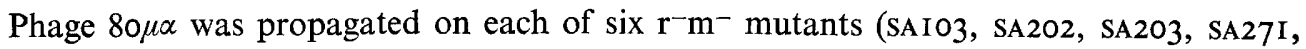
SA272 and SA282) and the resulting lysates were tested for e.o.p. on NCTC8325, SAII3 and all the $\mathrm{r}^{-} \mathrm{m}^{-}$mutants (Table $\mathrm{I}$ ). All phage lysates were restricted by NCTC8325, confirming that these mutants are all deficient in a modification system. None of the lysates was restricted on SAII 3 or on the three $\mathrm{m}^{-}$mutants derived from it, confirming that they are all restriction deficient. However, the other three $\mathrm{r}^{-} \mathrm{m}^{-}$mutants were still able to restrict some of the phage lysates used. Thus SA27I and SA272 restricted phages grown on SAI03, SA202 and SA282; and SAIO3 poorly restricted phages grown on SA203, SA27I and SA272. 
Table 2. Presumed phenotype of mutants isolated from $\mathrm{NCTC} 8325$

\begin{tabular}{|c|c|c|c|c|}
\hline \multirow[b]{2}{*}{ Strain } & \multicolumn{4}{|c|}{ Host-specificity phenotype } \\
\hline & $\mathbf{r}_{\mathrm{S}_{1}}$ & $\mathrm{~m}_{\mathrm{s} 1}$ & $\mathrm{r}_{\mathrm{S} 2}$ & $\mathrm{~m}_{\mathrm{82}}$ \\
\hline SAIO3 & \pm & + & - & - \\
\hline $\left.\begin{array}{l}\text { SA202 } \\
\text { SA282 }\end{array}\right\}$ & - & + & - & - \\
\hline SA203 & - & - & - & + \\
\hline SA27I & - & - & \pm & + \\
\hline SA272 & - & - & $\bar{t}$ & + \\
\hline SAII3 & - & + & - & + \\
\hline NCTC 8325 & + & + & + & + \\
\hline
\end{tabular}

Table 3. Host-specificity phenotypes of the restriction-deficient mutants isolated by screening with $80 \mu \alpha$.S I and $80 \mu \alpha . \mathrm{S}_{2}$ phage stocks

\begin{tabular}{cccc}
\multicolumn{4}{c}{ Phenotype* } \\
$\mathrm{r}_{\mathrm{s} 1}$ & $\mathrm{~m}_{\mathrm{s} 1}$ & $\mathrm{r}_{\mathrm{S} 2}$ & $\mathrm{~m}_{\mathrm{S} 2}$ \\
- & + & - & + \\
\pm & + & \pm & + \\
- & \pm & + & + \\
- & - & + & + \\
+ & + & - & \pm \\
\pm & + & - & \pm \\
+ & + & - & -
\end{tabular}

\begin{tabular}{|c|c|}
\hline \multicolumn{2}{|c|}{$\begin{array}{l}\text { No. of mutants selected } \\
\text { with phage stock: }\end{array}$} \\
\hline $80 \mu \alpha . S I$ & $80 \mu \alpha . S_{2}$ \\
\hline 2 & 3 \\
\hline 3 & 4 \\
\hline 0 & I \\
\hline 0 & 2 \\
\hline 2 & 0 \\
\hline I & 0 \\
\hline 2 & 0 \\
\hline IO & 10 \\
\hline
\end{tabular}

* For both host-specificity systems, $\mathrm{r}^{-}$phenotype corresponds to an e.o.p. between $5 \cdot 0 \times \mathrm{IO}^{-1}$ and $\mathrm{I} \cdot 0$, $\mathrm{r}^{ \pm}$to an e.o.p. between $5^{\circ} 0 \times 10^{-1}$ and $2.0 \times 10^{-3}$, the e.o.p. of the same unmodified phage lysate being less than $2.0 \times \mathrm{IO}^{-3}$ on $\mathrm{r}^{+}$. The modification phenotype of a mutant was scored according to the e.o.p. on NCTC8325 of a phage lysate obtained on this mutant: $\mathrm{m}^{+}$corresponds to an e.o.p. between $5.0 \times 10^{-1}$ and $\mathrm{I} \cdot 0 ; \mathrm{m}^{ \pm}$between $2.0 \times 10^{-3}$ and $5.0 \times 10^{-1} ;$ and $\mathrm{m}^{-}$less than $2.0 \times 10^{-3}$.

One possible explanation of these results is that there are two restriction and modification systems in $S$. aureus NCTC8325. The phenotypes of the strains would then be as shown in Table 2.

Some of the mutants previously isolated were retested for their restriction and modification properties and, in agreement with the explanation proposed above, mutants with $\mathrm{r}^{-} \mathrm{m}^{+}$and $\mathrm{r}^{ \pm} \mathrm{m}^{+}$phenotypes all proved to be $\mathrm{r}_{\mathrm{s} 1}^{-} \mathrm{m}_{\mathrm{s} 2}^{+} \mathrm{r}_{\mathrm{s} 2}^{-} \mathrm{m}_{\mathrm{s} 2}^{+}$and $\mathrm{r}_{\mathrm{s} 1}^{ \pm} \mathrm{m}_{\mathrm{s} 1}^{+} \mathrm{r}_{\mathrm{s} 2}^{ \pm} \mathrm{m}_{\mathrm{s} 2}^{+}$respectively. On the other hand, $\mathrm{r}^{-} \mathrm{m}^{-}$and $\mathrm{r}^{-} \mathrm{m}^{ \pm}$mutants were modification deficient in only one system and were always $\mathbf{r}^{-}$in the same system, irrespective of the restriction phenotype of the other system.

We attempted to isolate new restriction-deficient mutants of NCTC 8325 by screening with phage stocks that lacked only one of the two NCTC8325-specific modifications. The results are summarized in Table 3. Three out of $10 r_{\mathrm{sI}}^{-}$mutants and five out of $10 r_{\mathrm{s} 2}^{-}$mutants were modification deficient in the same system. These mutants were, with one exception (Table 3, line 6), unaffected in the restriction and modification abilities of the other system. Mutants affected only in restriction properties were always restriction deficient in both systems, regardless of the phage stock used for screening.

In another experiment, $\mathrm{r}_{\mathrm{s} 2}^{-}$mutants were selected from $\mathrm{SA2} 22\left(\mathrm{r}_{\mathrm{s1}}^{-} \mathrm{m}_{\mathrm{s} 1}^{-} \mathrm{r}_{\mathrm{s} 2}^{+} \mathrm{m}_{\mathrm{s} 2}^{+}\right)$, and three out of $\mathrm{I} 8$ isolated mutants were $\mathrm{r}_{\mathrm{s} 2}^{-} \mathrm{m}_{\mathrm{s2}}^{-}$. One of the $\mathrm{r}_{\mathrm{s} 1}^{-} \mathrm{m}_{\mathrm{S1}}^{-} \mathrm{r}_{\mathrm{S} 2}^{-} \mathrm{m}_{\mathrm{s} 2}^{-}$mutants (SA328) was used to obtain $80 \mu \alpha$.So stocks. 
Table 4. Efficiencies of plating of $80 \mu \alpha$ lysates on prototype strains

\begin{tabular}{|c|c|c|c|c|}
\hline \multirow[b]{2}{*}{ Phage stock } & \multicolumn{4}{|c|}{ Efficiency of plating* on strain: } \\
\hline & $\begin{array}{l}\mathrm{SAI} I 3 \\
\mathrm{r}_{\mathrm{S} 1}^{-} \mathrm{r}_{\mathrm{S} 2}^{-}\end{array}$ & $\begin{array}{c}\mathrm{sA272} \\
\mathrm{r}_{\mathrm{S1}}^{-} \mathbf{r}_{\mathrm{S2}}^{+}\end{array}$ & $\begin{array}{r}\mathrm{SA326} \\
\mathrm{r}_{\mathrm{S1}}^{+} \mathrm{r}_{\mathrm{S2}}^{-}\end{array}$ & $\begin{array}{c}\mathrm{NCTC}_{3325} \\
\mathrm{r}_{\mathrm{S1}}^{+} \mathrm{r}_{\mathrm{S2}}^{+}\end{array}$ \\
\hline 8o $\mu \alpha$.So & $\mathbf{I} \cdot \mathbf{O}$ & $6.8 \times 10^{-4}$ & $8.3 \times 10^{-4}$ & $5.1 \times 10^{-4}$ \\
\hline $80 \mu \alpha$. SI & $I \cdot 0$ & $1 \cdot 4 \times 10^{-3}$ & $1 \cdot 0$ & $9.4 \times 10^{-4}$ \\
\hline $80 \mu \alpha . S_{2}$ & $I \cdot O$ & $\mathrm{I} \cdot \mathrm{O}$ & $2 \cdot 3 \times 10^{-4}$ & $2.5 \times 10^{-4}$ \\
\hline $80 \mu \alpha . \mathrm{SI}_{1}, \mathrm{~S}_{2}$ & $I \cdot 0$ & $I \cdot 0$ & $I \cdot 0$ & $I \cdot 0$ \\
\hline
\end{tabular}

With the complete set of host-specificity mutants of NCTC8325, we examined the relationship between the two identified host specificities. Although the two specificities are distinct and both are active on $80 \mu \alpha$.So, their restrictions are not additive (Table 4). The e.o.p. of $80 u \alpha$.So on NCTC8325 was of the same order of magnitude as the e.o.p. of phage stocks carrying one modification. Moreover, $\mathrm{r}_{\mathrm{s} 1}^{-} \mathrm{r}_{\mathrm{s} 2}^{+}$and $\mathrm{r}_{\mathrm{s} 1}^{+} \mathrm{r}_{\mathrm{s2}}^{-}$mutants restrict 8o $\mu \alpha$. So at about the same level as $r_{\mathrm{s} 1}^{+} r_{\mathrm{s} 2}^{+}$.

\section{Other properties of $\mathrm{r}_{\mathrm{s} 2}^{-} \mathrm{m}_{\mathrm{B} 2}^{-}$mutants}

Strain RN98I was, in our notation, $\mathrm{r}_{\mathrm{S1}}^{+} \mathrm{m}_{\mathrm{s1}}^{+} \mathrm{r}_{\mathrm{s2}}^{-} \mathrm{m}_{\overline{\mathrm{S2}}}^{-}$. Wyman et al. (I974) suggested that this strain carries two mutations - one responsible for the genetic recombination and modification deficiencies and mitomycin $\mathrm{C}$ sensitivity, and the other controlling the ultravioletsensitive and $r^{-}$phenotype. According to this hypothesis, the $r_{\mathrm{s} 2}^{-} m_{\mathrm{s2}}^{-}$mutants would be expected to have an ultraviolet- and mitomycin-sensitive phenotype, as well as being recombination deficient. Thus, five independently isolated, one-step $r_{\mathrm{s} 2}^{-} m_{\mathrm{s2}}^{-}$mutants were tested for these properties. They all showed a response to u.v.-irradiation similar to that of NCTC8325, and in contrast to the high u.v. sensitivity of RN98I. The minimal inhibitory concentration (m.i.c.) of mitomycin $\mathrm{C}$ was the same $\left(0.1 \mu \mathrm{g} \mathrm{ml}^{-1}\right)$ for NCTC8325 and all but one of the mutants, the exceptional mutant having an m.i.c. of $0.06 \mu \mathrm{g} \mathrm{ml}^{-1}$. Two of the $\mathrm{r}_{\mathrm{S2}}^{-} \mathrm{m}_{\mathrm{s2}}^{-}$mutants were isolated from SA272. They were lysine-dependent like SA272, although this was originally only selected as restriction deficient. When used as recipients, these mutants gave $\mathrm{Lys}^{+}$transductants at a similar frequency to the parental strain, suggesting that they were $\mathrm{Rec}^{+}$. Thus, it is unlikely that the same genes are involved in host specificity $\mathrm{S} 2$, and in recombination proficiency and u.v. resistance.

\section{DISCUSSION}

The isolation and characterization of restriction- and modification-deficient mutants of $S$. aureus NCTC8325 suggests the existence of two host specificities in this strain. Two hostspecificity systems have been reported in other bacterial strains, e.g. $\mathrm{P}_{1}$ and $\mathrm{K}$ (Lederberg, I957) or A and 15 (Arber \& Wauters-Willems, 1970) in Escherichia coli; L and SA (Colson \& Colson, I97I) or SA and SB (Colson \& Van Pel, 1974) in Salmonella typhimurium; and AI and A2 (Piekarowicz \& Glover, I972) in Haemophilus influenzae Ra. In all these examples, the two systems are approximately additive in their restricting action. Furthermore, restriction-deficient mutants isolated in one system are only exceptionally affected in the restriction ability of the other system. In NCTC8325, the restricting action of the two systems is not additive, and mutants that are restriction deficient in both systems were isolated in one step. These facts can best be explained by assuming that the two systems use the same gene (hsr) coding for a specific sub-unit of the restrictive endonuclease, although the 
alternative explanation that two $h s r$ genes were affected by NTG-induced multiple mutations cannot be entirely ruled out. The proportion of modification-deficient mutants among $\mathrm{r}^{-}$ mutants was high. It is likely therefore that both systems are of Type I (Boyer, I97I) and that the three-gene model (Glover, 1970; Hubacek \& Glover, 1970) applies to the two systems.

Since no $\mathrm{m}_{\mathrm{s} 1}^{-} \mathrm{m}_{\mathrm{s} 2}^{-}$or $\mathrm{m}_{\mathrm{s} 1}^{ \pm} \mathrm{m}_{\mathrm{s} 2}^{ \pm}$were isolated in one step, two distinct $h s m$ genes may be present. However, these two hsm genes may complement each other and $\mathrm{r}^{-} \mathrm{m}^{-}$mutants isolated in one or two steps in either system may be due to mutations in hss genes.

The presence of the two specificities in NCTC8325 allows a partial explanation of the results obtained previously (Iordanescu, 1975). The use for screening of phage 8o $\mu \alpha . P S 80$ that behaves like $80 \mu \alpha$.So on NCTC8325 led to preferential isolation of mutations in the $h s r$ gene, since $\mathrm{r}_{\mathrm{s} 1}^{-} \mathrm{m}_{\mathrm{s} 1}^{-} \mathrm{r}_{\mathrm{s} 2}^{+} \mathrm{m}_{\mathrm{s} 2}^{+}$or $\mathrm{r}_{\mathrm{s} 1}^{+} \mathrm{m}_{\mathrm{s} 1}^{+} \mathrm{r}_{\mathrm{s} 2}^{-} \mathrm{m}_{\mathrm{s} 2}^{-}$mutants restricted $80 \mu \alpha . \mathrm{PS} 80$ to the same extent as did the parental strain NCTC8325.

The relationship between the two host specificities of NCTC8325 suggests that they may have arisen by tandem duplication of an ancestral set of host-specificity genes, followed by divergent evolution at least of the hss genes.

We acknowledge the excellent technical assistance of Mary Kövary and Ileana Stuparu.

\section{REFERENCES}

Adelberg, E. A., MANDel, M. \& Chen, G. C. C. (1965). Optimal conditions for mutagenesis by $N$-methyl$N^{\prime}$-nitro- $N$-nitrosoguanidine (NTG) in Escherichia coli KI2. Biochemical and Biophysical Research Communications 18, 788-795.

ARbER, W. \& LINN, S. (1969). DNA modification and restriction. Annual Review of Biochemistry 38, 467-500. ARBER, W. \& WAUTERS-WILlems, D. (1970). Host specificity of DNA produced by Escherichia coli. XII.

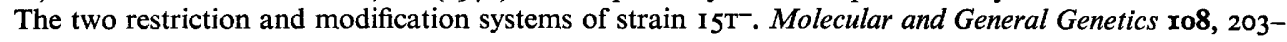
217.

Asheshov, E. A. \& Jevons, P. (1963). The effect of heat on the ability of a host strain to support the growth of a staphylococcus phage. Journal of General Microbiology 31, 97-107.

BOYER, H. W. (I97I). DNA restriction and modification mechanisms in bacteria. Annual Review of Microbiology 25, I 53-I 76.

Colson, C. \& Colson, A. M. (I97I). A new Salmonella typhimurium DNA host specificity. Journal of General Microbiology 69, 345-35I.

Colson, C. \& VAN PeL, A. (I974). DNA restriction and modification systems in Salmonella. I. SA and SB, two Salmonella typhimurium systems determined by genes with a chromosomal location comparable to that of the Escherichia coli hsd genes. Molecular and General Genetics 129, 325-337.

GLOVER, S.W. (1970). Functional analysis of host specificity mutants in Escherichia coli. Genetical Research $\mathbf{1 5}$, 237-250.

HubaceK, J. \& Glover, S. W. (1970). Complementation analysis of temperature-sensitive host specificity mutations in Escherichia coli. Journal of Molecular Biology 50, I I I-I 27.

IORDANESCU, S. (1975). Host controlled restriction mutants of Staphylococcus aureus. Archives roumaines de pathologie expérimentale et de microbiologie $34,55-58$.

LEDERBERG, S. (I957). Suppression of the multiplication of heterologous bacteriophages in lysogenic bacteria. Virology 3, 496-513.

Novick, R. P. (I963). Analysis by transduction of mutations affecting penicillinase formation in Staphylococcus aureus. Journal of General Microbiology 33, $12 \mathrm{I}-\mathrm{1} 36$.

Novick, R. P. (I967). Properties of a cryptic high-frequency transducing phage in Staphylococcus aureus. Virology 33, I 55-166.

Piekarowicz, A. \& Glover, S. W. (1972). Host-specificity of DNA in Haemophilus influenzae. The two restriction and modification systems in strain Ra. Molecular and General Genetics I16, I I-25.

RAlston, D. J. \& BAER, B. S. (1964). A new property of phage group II Staphylococcus aureus strains: host restriction of phage KI4. Journal of General Microbiology 36, I-I6.

RountreE, P. M. (1956). Variations in a related series of staphylococcal bacteriophages. Journal of General Microbiology $\mathbf{1 5}, 266-279$.

Stobberingh, E. E. \& WinkLer, K. C. (1975). Restrictionless mutants of Staphylococcus aureus. Antonie van Leeuwenhoek 4I, $212-213$.

Wyman, L., Goering, R. V. \& Novick, R. P. (1974). Genetic control of chromosomal and plasmid recombination in Staphylococcus aureus. Genetics 76, 681-702. 